\title{
RESTORATIVE JUSTICE AS AN ALTERNATIVE CRIMINAL DISPUTE RESOLUTION FOR THE OFFENCE OF THEFT
}

\author{
Norjihan Ab Aziz ${ }^{1 *}$, Noorshuhadawati Mohamad Amin² and Zuraini Ab Hamid ${ }^{3}$ \\ ${ }^{1}$ Assist. Prof. Dr., International Islamic University Malaysia, Malaysia, norjihanabaziz@iium.edu.my \\ ${ }^{2}$ Ph.D student, International Islamic University Malaysia, Malaysia, shuhadaamin@iium.edu.my \\ ${ }^{3}$ Assist. Prof. Dr., International Islamic University Malaysia, Malaysia, zuraini.abhamid@gmail.com \\ ${ }^{*}$ Corresponding author
}

\begin{abstract}
Under the traditional justice system, theft is an offence against a state. Once the offender is found guilty by the court, he will be punished accordingly. In Malaysia, the Penal Code provides punishment for an offence of theft with imprisonment for a term not exceeding 7 years, or fine or with both. The aim is to punish the offender for the offence that he had committed, while the victim has no place in the process. However, restorative justice sees a crime is against an individual which allows the offender to be direct accountability against the victim. In other words, instead of punishing the offender for an offence done, the offender has to repair the harm suffered by the victim such as by paying compensation or in case of theft restore the stolen property to the victim. Islamic law has implemented restorative justice long time ago to allow certain criminal cases to be resolved between the parties, provided that the case has not been reached to the authority. Restorative justice has been recognized internationally by the United Nation, which encourages criminal cases which are minor in nature, such as theft, vandalism, and hurt to be resolved through the restorative justice process. As such, many countries have implemented restorative justice, such as the United Kingdom, the United States, Australia and New Zealand. Restorative justice can be considered as an alternative to the traditional justice system which allows the offender and the victim resolve criminal offence with the assistance of a neutral third party out of court. For instance, in the offence of theft, instead of punishing the offender, the case can be resolved if the offender agrees to seek forgiveness and returns the stolen item or pays compensation to the victim, and the victim agrees to reintegrate the accused into the society. Thus, this research aims to examine the law of Malaysia that governs the offence and the punishment of theft. This research also analyses how restorative justice is implemented under the United Nation and Islamic law. It is suggested that the Malaysian law that governs the offence of theft to be improvised so that the parties may opt to resolve criminal cases through restorative justice.
\end{abstract}

Keywords: theft, restorative justice, punishment

\section{INTRODUCTION}

The offence of theft is always associated with poverty, high cost of living and jobless. In Malaysia, there are cases where food was stolen due to no money to buy. For example, in March, 2016 a woman was sentenced to a day's jail and fined RM200, in default to five days' jail, for stealing the $2 \mathrm{~kg}$ Milo for her two-year-old child 
in a supermarket in Kuala Lumpur. The mother pleads that she had no money to but the Milo for her child (The Star, $3^{\text {rd }}$ March 2016). On another occasion, it was reported that a 31-year-old jobless man was detained by security personnel at a Tesco branch in Bukit Mertajam for stealing fruit and canned drinks. The suspect claimed that he had no money to buy food for his three children, aged between two and seven, who were starving, while his wife was in hospital after suffering a miscarriage. Instead of lodging a police report, the suspect was offered with a job by the Tesco. No action was taken against the suspect. The staff even visited the suspect's wife and house, and offer helps to the suspect (The Star, 15 ${ }^{\text {th }}$ March 2016). In April, 2016 two men were each jailed 10 months by the Magistrate's Court Kota Kinabalu for stealing six packets of Milo from a supermarket (The Borneo Post, $23^{\text {rd }}$ April 2016). In Perak, there was a theft case committed by a public university student and her mother for stealing 17 packets of Nescafe from a hypermarket in Kampar on April, 16. The mother claims that she did not have enough money for her daughter's daily expenses at the university (Malay Mail, $17^{\text {th }}$ April 2016).

Referring to the above scenario, it reflects that the offenders have to commit such crime to survive due to monetary problems. Instead of punishing the offenders, they need to be assisted. Restorative justice approach is the best solution to resolve this kind of issue. The traditional justice system as implemented in Malaysia, merely to punish the offender based on the law provided. Unlike the traditional justice system, the restorative justice gives opportunity to the accused and the victim to resolve the case out of courts based on their needs and interests. For example, the case is considered resolvable if the victim is willing to forgive the offender and accepts compensation or the offender agrees to return the stolen item to the victim. This can expedite the disposal of criminal cases, as well as minimize pending and appeal cases.

\section{OFFENCE AND PUNISHMENT OF THEFT UNDER THE PENAL CODE OF MALAYSIA}

Section 378 of the Penal Code provides that a person commits theft if he intends to take dishonestly any movable property out of the possession of any person without the person's consent, and moves that property in order to such taking. The punishment for the offence of theft as stated in section 379 of the Penal Code is imprisonment for a term which may extend to seven years, or with fine, or with both, and for a second or subsequent offence shall be punished with imprisonment and fine or whipping. If the offence of theft is committed in any building such as in a shopping complex or in a shop, he shall be punished with imprisonment for a term which may extend to ten years, and liable to fine, and for a second or subsequent offence, shall be punished with imprisonment and be liable to fine or to whipping (Mohamad Shariff and Asidah, 2012,460).

\subsection{Criminal Dispute Resolution for the Offence of Theft under the Criminal Procedure Code of Malaysia}

In Malaysia, the offence of theft can be resolved either by way of litigation or plea bargaining. These processes are governed by the Criminal Procedure Code 2012.

\subsubsection{Litigation under section 173 of the Criminal Procedure Code}

Litigation is available in criminal cases in court where a decision is made by the judge after a trial. Litigation is a process of resolving disputes within the framework of the judicial system which is defined by statutes and rules adopted by the legislature and courts. Litigation also can be defined as a process defined and governed by rules that must be understood and applied in different ways in different settings to enforce the rights and obligations established by the substantive law (Susan, 2009,2). Thus, litigation is a process of dispute resolution heard in the court which is set by certain rules and procedure.

The procedure of summary trials by the Magistrate Court is governed by section 173 of the Criminal Procedure Code 2012. When the accused is brought before the court, the charge which contains the details of the offence shall be read and explained to the accused. In this regard, the accused may either plead guilty or claim trial. If the accused plead guilty to the charge, the Court shall pass sentence accordingly.

The accused may claim trial or refuses to plead guilty. The Court may take all evidences to support prosecution case. At the hearing the prosecutor has to satisfy a prima facie case against the accused by adducing credible evidence to prove the necessary elements of an offence which if unrebutted or unexplained would warrant a conviction. At the end of the prosecution case, the Court shall determine whether the prosecution has made a prima facie case against the accused. If there is no prima facie case against the accused, the Court shall order an acquittal. The Court may also discharge the accused if satisfied that the charge is groundless.

If the court convinced that there is a prima facie case against the accused, the court should call the accused 
to enter on his defence. The accused while entering on his defence, may opt to give sworn evidence in the witness box, to give unsworn statement from the dock, or to remain silent. The accused may produce his evidence, the accused may produce his evidence and cross examine any witnesses.

At the end of the trial, the court shall determine whether the prosecution has successfully proved beyond reasonable doubt. If the case has been proven beyond reasonable doubt, the accused will be held guilty, convicted of the offence and the Court shall pass sentence accordingly. Before the Court pass judgement, the Court may consider the victim's impact statement or statements of the victim's family on the implication of the crime. If the court satisfied that the prosecution has not proven the case beyond reasonable doubt, the accused shall be acquitted.

\subsubsection{Plea Bargaining under Section 172 of the Criminal Procedure Code}

In Malaysia, the process of plea bargaining can be held at the pre-trial conference or even during trial. Plea bargaining as defined by the Oxford Dictionary of Law is an agreement between the prosecutor and the accused by which the accused agrees to plead guilty to a lesser charge as offered by the prosecution (Oxford Dictionary, 2009, 408). Plea bargaining is "a process where the prosecution and the defence makes an attempt to achieve a compromise to allow the accused to plead guilty on certain conditions" (Textbook). There are two kinds of plea bargaining; namely plea bargaining on charge or sentencing. Plea bargaining on charge is where the accused and the prosecution agree that the accused plead guilty to a lesser charge while plea bargaining on sentencing is where the accused agrees to plead guilty to the original charge provided that he will be sentenced with a lenient sentence (Baljit, 2011, 294). Pursuant to the amendment of the Code recently, pleading guilty provides the accused with a statutory right to a sentencing account.

An accused, if he claims to be tried, may make an application of plea bargaining regarding the charge or the sentence. The application shall be made in form 28A of the Second Schedule and shall contain a brief description of the offence, a declaration by the accused stating that the application is made voluntarily after understanding the nature and extent of the punishment and information as to whether the plea bargaining applied for the sentence or the charge. If plea bargaining is to the charge, the accused will be sentenced as stated in the Penal Code for that particular offence. However, if the plea bargaining is to sentence, the accused can be punished with compensation. In case where the offender is a youthful offender, he can be discharged for admonition, order good behaviour, order community service or whipping with a light cane. The court may release the accused on probation of good conduct or direct the accused to pay the costs of the prosecution. The Court may also sentence the accused not more than half of the maximum punishment of imprisonment under the law where the accused convicted. For example, if the accused was charged with theft, the punishment under section 379 of the Penal Code is seven years imprisonment or fine or both. If the accused apply for plea bargaining on the sentence, plead guilty and convicted, the accused can be imprisoned not more than three years and six months.

If the court satisfied that the accused has made the application of plea bargaining voluntarily, the public prosecutor and the accused should start negotiation on a satisfactory disposition of the case. During the negotiation process, the parties merely discuss whether to accept a plea on the reduction of sentence or offence. Nature of sentence that will be imposed on the accused will not be discussed by the parties. If the court found that the application is made involuntarily by the accused, the court shall dismiss the application and the case shall proceed before another court for trial.

In case the accused and the prosecution agreed to a satisfactory disposition, it shall be put into writing and signed by the accused, the advocate and the public prosecutor. The court shall give effect to the satisfactory disposition as agreed upon by the accused and the public prosecutor. In other words, if the parties agree on a reduction of charge, the accused has to plead guilty to the amended charge and the Court will pass sentence based on the new charge. If the parties agree on reduction of sentence, the Court will decide the sentence according to section 172D of the Criminal Procedure Code 2012. The parties have no right to determine or discuss matters about the sentence as it will infringe the power of the Court to determine sentence. Otherwise, if no satisfactory disposition has been reached by the accused and the prosecution, the court shall record the result accordingly and the case shall proceed before another court for trial. This is to avoid bias from the judge if the same judge hears the trial (Baljit, 2011, 296). The court also has to ensure that the whole process of plea bargaining in reaching a satisfactory disposition, is voluntarily by the parties.

Where a satisfactory disposition of the case has been reached by the accused and the prosecution, the court may dispose of the case based on section 172C of the Criminal Procedure Code 2012 that is an order for payment of the cost of prosecution and compensation. If the satisfactory disposition is concerning the charge, the accused shall be guilty on the charge as agreed and the accused shall be sentenced accordingly. However, if a satisfactory disposition is on sentence, the accused shall be guilty on the charge 
and the accused may be dealt under youthful offenders or first offenders or the accused may be sentenced not more than half of the maximum punishment of imprisonment provided in the law.

The punishment of half of maximum punishment of imprisonment is not applicable if the accused has been convicted and punished for repeated offence, the offence is serious in nature whereby the maximum term of imprisonment is more than ten years. In this case, the accused shall be punished with more than half of the maximum sentence as prescribed in the law. If there is a minimum term of imprisonment provided under the law for the offence, the accused shall not be sentenced lesser than the minimum term.

In case parties agree and reach a satisfactory disposition, the court must be informed whether the satisfactory disposition is concerning sentence or charge. The court has to impose sentence provided in section 172D of the Code. If no satisfactory disposition has been agreed, the court will fix a date for trial and the case will be transferred to another court to be heard by a different judge. Nevertheless the parties merely discuss on satisfactory disposition either on reduction of the charge or reduction of sentence as applied by the accused in his application of plea bargaining. The parties have no right to discuss the type of sentence as it amounts to infringe power of the Court. However, it could be a miscarriage of justice if the accused plead guilty of an offence due to the plea bargaining agreement with the prosecutor, later found that the sentence passed by the Court is not as guaranteed by the prosecutor. In this regard, the Court is not the party in the process of plea bargaining and does not involve in any agreement between the parties. The power of the Court vested in the Criminal Procedure Code allows the Court to pronounce judgment as governed by the law (Baljit, 2011, 294).

\section{DEFINITION OF RESTORATIVE JUSTICE}

Restorative justice is a process where all victims and the offender in a particular offence get together to negotiate the offence and its implications in the future. Article 2 of the Basic Principles on the Use of Restorative Justice Programmes in Criminal Matters stipulates that restorative process means any process where both the victim and the offender with community members affected by crime, participate in resolving the criminal case with the help of a facilitator.

The philosophy of restorative justice comprises of three components; crime is viewed primarily as a conflict between individuals and secondarily as a violation against the state, the aim of the criminal justice process is to reconcile the parties and repair the injuries caused by the disputes and the criminal justice process shall facilitate the victims, offender and the communities to find a solution to the conflict (Robert and Laura, 2010, 107). The aim of restorative justice is to reconcile the victim and the offender by repairing the harm through the criminal justice process participated by the victims, offender and communities (Heather, 2004, 44).

The offender and the victim are the participants in the process and they are allowed to exchange information about the crime such as reasons for committing the crime and how the victim suffers from the crime (Bazemore and Schiff, 2003, 46). The offender has an obligation towards the victim by understanding the harm that affected victims and repairs the harm through compensation or making reparation while the community shall support and assist the victims to meet their needs and integrate the offender into the community (Heather, 2004, 41). The ordinary members of the community must involve in the resolution of conflict as a facilitator or mediator to support the victims and monitor the offender (David and Micheal, 2006, 152).

\subsection{Restorative Justice under the United Nation on Basic Principles on the Use of Restorative Justice Programmes in Criminal Matters.}

The UN Resolution has established specific standards and guidelines concerning restorative justice, which include the process, the parties, the outcome and the facilitator. Its objective is to the assist the member states of the United Nations to adopt and standardise restorative justice in their criminal justice systems, especially to deal with minor offences by using mediation and working out to seek civil reparation or compensation, and to consider community service, as alternatives to imprisonment (Mark and Marilyn, 2010, 281).

The UN Resolution defines the restorative process as any process where the victim together with the offender and any other individuals or community members participate in resolving criminal matters with the assistance of a third party(emphasis added). Generally, during the restorative process, the parties exchange information about the crime, discuss on how to repair the harm and to reconcile based on the parties' satisfaction and the restorative standards (Margarita, 2013, 49). All communication during the restorative process which is made in private settings is confidential and should not be disclosed except with the agreement of the parties or as required by national law. 
Parties in the restorative process are the persons directly affected by the crime which may include the victim, the offender and the community. Article 7 of the UN Resolution provides that the restorative process is only applicable if the offender has been charged with an offence and agreed to resolve the offence by way of restorative justice. The process is not compulsory for the parties and if the parties wish, they may resolve the case in trial. Hence, the offender and the victim may withdraw the consent at any time during the process.

The restorative justice process is facilitated by a mediator. The role of a facilitator in the restorative process is to facilitate the communication between the victim and the offender during negotiation. Hence, the facilitator shall not interfere during the discussion and shall not make any decision or evaluation as about the agreement arising from the process (Mark and Marilyn, 240).

The victim and the offender must agree on the facts of the case. The outcome of the restorative process is an agreement that is reached between the offender and the victim during the process. It may include restitution, community service, reparation of the victim and community, and reintegration of the victim and the offender. The agreement must be reached voluntarily and reasonably. Though the agreement can only be decided by the offender and the victim, it does not deny the role of the facilitator to ensure that the parties understand what they have agreed upon. The agreements should be judicially supervised or incorporated into judicial decisions or judgements and the offender should not be prosecuted for an offence of the same facts. In other words, the parties are bound by the agreement since the agreement can be considered as a judgment of the court through a 'Consent Order' (Article 15 of the UN Resolution).

Based on article 16 of the UN Resolution, if there is no agreement reached, the case should be referred to the criminal justice process and the court shall decide according to law. However, the case shall not be used in subsequent criminal justice proceedings. Besides, in case the parties have reached an agreement, but the offender or the victim is unable to fulfil the condition as agreed, the case also should be referred to the restorative programme or to the criminal justice process. If any parties fail to complete the agreement other than a judicial decision or judgement, the offender shall not be subject to a severe sentence in subsequent criminal justice proceeding.

In case the restorative process is not suitable or impossible to resolve a criminal case, the case should be referred to the criminal justice authorities without delay. The authority shall encourage the offender to take responsibility towards the victim and affected communities, and support the reintegration of the victim and the offender into the community before proceeding the case to trial (Article 4 of the UN Resolution). Any communication made by the parties during the mediation process shall not be used as evidence of an admission of guilt in subsequent legal proceedings.

\section{SUGGESTIONS AND RECOMMENDATIONS}

The United Nation has recognized and encouraged the restorative justice process should be implemented to resolve minor criminal offences such as theft. Hence, the same shall be implemented in Malaysia. It is possible to resolve minor criminal cases through restorative justice by seeking apologies from the victim, and make reparation to the victim or the community. In case of theft, this can be happened by returning the stolen item to the victim, or pay compensation to the victim. Hence, the case is resolved if the victim is ready to forgive the accused and accepts reparation made by the accused.

Without litigation and punishment, the restorative justice process has actually protected the right of the victim and the accused. By allowing the restorative justice process to resolve the offence of theft, the victim's right over his property can be restored by receiving the stolen item or compensation by the accused. The accused, instead of subjecting to fine, or imprisonment, can simply be released once had fulfilled the agreement with the victim. Thus, it is suggested that restorative justice shall be recognized under the Criminal Procedure Code and be implemented in Malaysia so that the parties may have wider options to resolve criminal cases particularly when involve minor offences including theft.

\section{CONCLUSION}

Dispute resolution for the offence of theft in Malaysia is restricted to litigation or plea bargaining, where the consequence is to punish the offender based on the law provided. The law does not allow the accused and the victim to resolve the offence of theft out of court between them. It is either to resolve by way of litigation or plea bargaining. Somehow it will cause burdensome to the accused if the value of the stolen item is less and it is actually can be resolved outside the court, especially if the victim agrees to accept the stolen item or compensation from the accused and to withdraw the complaint.

Since the United Nation allows the restorative justice process to be implemented to resolve minor criminal cases, the same shall be applied in Malaysia. It is believed that the restorative justice process helps to 
expedite the criminal cases, minimize pending and appeal cases, and litigation is not necessary unless the accused fails to fulfill the condition as agreed.

\subsection{ACKNOWLEDGEMENT}

This research was financially supported by the Research Initiative Grant Scheme (RIGS) 2016 (Project ID RIGS16-252-0416).

\section{REFERENCE LIST}

Baljit Singh Sidhu. (2011). Criminal Litigation Process. Malaysia: Sweet \& Maxwell Asia.

Bazemore, S. (2003). Juvenile Justice Reform and Restorative Justice: Building Theory and Policy from Practice. Portland: Willian Publishing.

David, S.,\& Michael, B. (2006). Mediation Law and Practice. New York: Cambridge University Press.

Heather, S. (2004). Repair or Revenge: Victims and Restorative Justice. Oxford: Clarendon Press.

Lo, T.C. (2016). Tesco offers shoplifter a job.http://www.thestar.com.my/news/nation/2016/03/15/tescooffers-shoplifter-a-job-mans-dire-situation-touched-our-hearts/.

Margarita, Z. (2007). Restorative Justice: Ideals and Realities. England: Ashgate Publishing Limited.

Mark, S. U., \&Marilyn, P. A. (2010).Restorative Justice Dialogue:

An Essential Guide for Research and Practice. (New York: Springer Publishing Company.

Mohamad Shariff Abu Samah, Asidah bt Mohd. Ali. (2012). Alman Criminal Law In Malaysia. Selangor: International Law Book Series.

Robert, A. J., \& Laura, J. M. (2010). The Victims of Crim. USA: Prantice Hall. Susan, B. L. (2009). California Civil Litigation. United States of America: Delmare Cengage Learning.

The Borneo Post. (2016). Duo jailed for Milo theft. http://www.theborneopost.com/2016/04/23/duo-jailed-formilo-theft/.

The Malay Mail. (2016). Mother and daughter caught for stealing packets of Nescafe coffee. http://www.themalaymailonline.com/malaysia/article/mother-and-daughter-caught-for-stealingpackets-of-nescafe-coffee.

The Star. (2016). Woman gets a day's jail for stealing Milo.

http://www.thestar.com.my/news/nation/2016/03/03/woman-gets-a-days-jail-for-stealing-milo/ 